nokształcącym, które dotychczas najczęściej interesowały historyków edukacji. Za interesujący problem uznał poszukiwanie odpowiedzi na pytania o stopień realizacji celów oświatowych władz państwowych oraz określenie, ile w nas samych pozostało wspomnień i nawyków ukształtowanych w okresie PRL-u. Wskazując kierunki dalszych badań zaznaczył, że skoro poznano już nauczycieli z tamtych lat, należy teraz podjąć nowy temat i spróbować odpowiedzieć na kolejne pytanie: jak to było „być uczniem w PRL-u”?.

Danuta Apanel

Agnieszka Wałega

Justyna Gulczyńska

\title{
II Ogólnopolska Konferencja Naukowa - Grupy etniczne wczoraj i dziś. Dyskurs nauki ze świadomą turystyką
}

W dniu 30 maja 2012 r. na Wydziale Studiów Edukacyjnych Uniwersytetu im. Adama Mickiewicza odbyła się druga z kolei ogólnopolska studencko-doktorancka konferencja naukowa „Grupy etniczne wczoraj i dziś. Dyskurs nauki ze świadomą turystyką”. Zorganizowana została przez studenckie Koło Naukowe Historii Kultury i Edukacji, a prowadzona była przez dr. Ratajczaka, Hannę Grzesiak i Mikołaja Fryzę. Konferencja odbyła się dzięki uprzejmości dziekana Wydziału Studiów Edukacyjnych prof. zw. dr hab. Zbyszka Melosika, prodziekan prof. zw. dr hab. Ewy Solarczyk-Ambozik oraz prof. UAM dr hab. Agnieszki Cybal-Michalskiej. Uczestnicy konferencji zostali uroczyście powitani przez dr. Krzysztofa Ratajczaka, który w wypowiedzi rozpoczynającej spotkanie nawiązał do etnogenezy, średniowiecznych pielgrzymek, które były okazją do poszukiwania i poznawania odrębnych kultur. Poruszony został również temat konieczności podejmowania badań interdyscyplinarnych, które najlepiej przeprowadzać zespołowo, „oczami” różnych fachowców. Referaty wygłoszone podczas konferencji dotyczyły zróżnicowanej tematyki, która spotkała się z aprobatą przedstawicieli czołowych uczelni, m.in. Uniwersytetu Warszawskiego, Uniwersytetu Jagiellońskiego, Państwowej Szkoły Wyższej im. Jana Pawła II w Białej Podlaskiej, Uniwersytetu Marii Curie-Skłodowskiej w Lublinie, Akademii Wychowania Fizycznego im. E. Piaseckiego w Poznaniu oraz Uniwersytetu im. Adama Mickiewicza. Wygłoszono piętnaście referatów, których autorami byli socjolodzy, pedagodzy, historycy, etnolodzy, dziennikarze. Niewątpliwie wielkim atutem przeprowadzonej konferencji były dyskusje przeprowadzane po każdym z wygłoszonych referatów.

Pierwszy referat wygłosił Bartosz Prabucki z Akademii Wychowania Fizycznego im. E. Piaseckiego w Poznaniu pt. „Sport jako aktywna odpowiedź grup etnicznych na skutki procesu globalizacji”. Autor zapoznał uczestników konferencji m.in. z popularyzacją piłki nożnej w Ameryce Południowej. Jako przykład dostosowania elementów globalnych do lokalnych światów podał kraj Basków, którego społeczeństwo początkowo było 
niechętne do piłki nożnej. Jednak stworzenie polityki cantery, dającej możliwość tylko urodzonym w kraju Basków członkostwo w drużynie, spowodowało zmianę podejścia ludności do tego sportu. Ciekawym faktem jest, że socios, czyli kibice są współwłaścicielami klubu. Płacąc składki, mają wpływ na decyzje klubu, który jest dobrem lokalnym. Baskowie prezentują silną tożsamość narodową, która jest wykorzystywana do promocji sportu. Innym przykładem społeczeństwa prezentowanego przez autora referatu są Katalończycy, którzy - podobnie jak Baskowie - stworzyli klub FC Barcelona, będący przedsiębiorstwem opartym na promocji etnicznej polityki. Do elementów tożsamości klubu możemy zaliczyć: cules (kibice), penas (kluby kibica), tożsamość etniczną, wartości społeczne, marka - oparta na wartościach etnicznych. Bartosz Pabucki zaprezentował również sporty tradycyjne, wywodzące się z poszczególnych grup etnicznych, które cechują się: różnymi źródłami pochodzenia, popularnością i żywotnością (jest ich ponad 7 tysięcy), różnorodnymi funkcjami społeczno-kulturowymi, stanowią element tożsamości etnicznej. Do sportów tradycyjnych możemy zaliczyć baskijską Pelotę, sporty szkockie (highland games), tradycyjne sporty polskie, takie jak: pierścieniówka, sztekiel, palant. W podsumowaniu autor referatu zwrócił uwagę słuchaczy na istotną rolę sportu w kształtowaniu części kulturalnej społeczeństw; służy również wielu grupom etnicznym jako element tożsamości lokalnej; jest aktywną odpowiedzią na globalizację; stanowi atrakcję kulturalną oraz jest elementem dziedzictwa kulturowego.

Kolejny referat wygłosił Dawid Dudek, pt. „Czy w starożytności istniały grupy etniczne”. Autor referatu zapoznał uczestników konferencji z etymologią słowa „etniczność kulturowa”. Wymienił elementy etniczności według Anthony’ego D. Smith’a, do których zalicza się: przekonanie o wspólnym pochodzeniu i wytwarzanie w tym celu np. mitów i legend; wspólne dzieje; wspólny obszar, jaki zamieszkuje (lub zamieszkiwała) społeczność; postrzeganie siebie jako odmiennych od innych (inny język, kultura); określanie siebie daną nazwą; poczucie tożsamości i wypracowanie więzi społecznych. Autor referatu wykazał, że pojęcie etniczności w obecnych czasach różni się diametralnie od tego z czasów starożytnych. Na przykładzie Grecji możemy wykazać, że pierwszy nie musiał istnieć określony obszar, by zaistniało państwo, najpierw bowiem była Wielka Grecja. Metodologia obecnie nam znana, nigdy w pełni nie zrozumie starożytnego świata.

„Stereotypy grup etnicznych w opinii studentów PSW w Białej Podlaskiej, przykład Lubelszczyzny", to tytuł kolejnego referatu wygłoszonego przez Jarosława Jakoniuka, przedstawiciela Państwowej Szkoły Wyższej im. Jana Pawła II w Białej Podlaskiej. Na podstawie przeprowadzonych badań poparta została hipoteza przedstawiająca nasz naród jako nietolerancyjny. Mimo że w czasach Konfederacji Warszawskiej uchodziliśmy za jeden z najbardziej tolerancyjnych krajów w Europie. Obecnie Polaków cechuje mnóstwo uprzedzeń, które możemy zaobserwować w życiu codziennym. Nie są obce nam opinie mówiące o tym, że Romowie kradna, Islam kojarzony jest wyłącznie z terroryzmem, a Niemcy są z natury źli.

Następnie został wygłoszony referat pt. „Bieszczadzkie Pompeje. Turystyka kulturowa minionego świata w Bieszczadach”, którego autorem jest Łukasz Bajda. Uczestnicy konferencji zostali wprowadzeni w tematykę regionalizmu Bieszczad, które są jednym 
z najbardziej rozpoznawanych terenów w Polsce. Dodatkowo region ten charakteryzuje mozaika etniczna, do której jako trzy podstawowe grupy etniczne zaliczają się: Bojkowie, Łemkowie, Dolinianie (najsłabiej poznana grupa etnograficzna). Autor referatu zaprezentował również instytucje krzewiące walory turystyczne tego rejonu, zaliczyć do nich można: Muzeum Historyczne w Sanoku, kolekcję strojów ludowych i haftów w Komańczy, Bieszczadzkie ekomuzea.

„Symboliczne i kulturowe wyobrażenia o mieszkańcach ziem zachodnich i północnych w wypowiedziach prymasa Stefana Wyszyńskiego oraz Episkopatu Polski” był to kolejny referat wygłoszony podczas konferencji. Jego autor, Adam Rajewski, starał się przybliżyć słuchaczom istotne oraz złożone stanowisko prymasa Wyszyńskiego i Episkopatu Polski dotyczące ziem zachodnich i północnych odwołujące się do historii narodu polskiego.

Następnie referat wygłosiła Agnieszka Pogorzelska pt. „Kształtowanie się polityki migracyjnej Unii Europejskiej wobec rozwiązań europejskiego modelu społecznego; instytucjonalne i prawne podejście do etniczności w UE”. Poruszone zostało zagadnienie dyskusji państw w zakresie wspólnych standardów europejskiego modelu społecznego, wynikającego z kwestii migracji ludności. Zagadnienie to jest istotne m.in. ze względu na konieczność zapewnienia ludności migracyjnej zabezpieczeń, np. socjalnych. Wymienione zostały cechy europejskiego modelu społecznego, do których zalicza się: centralizację; stosowanie strategii modelu społecznego; monopolizację usług; rozwój dialogu społecznego oraz aktywizację osób. Zagadnienie migracji społecznej i zapewnienie podstawowych zabezpieczeń jest o tyle istotne, że osoby te często są zagrożone wykluczeniem społecznym ze względu na zróżnicowanie pod kątem społecznym czy kulturowym. Autorka referatu na zakończenie podkreśliła rolę budowania społeczeństwa wielokulturowego, które powinno cechować się: dostosowaniem programu nauczania; dopasowaniem dni wolnych do świąt obowiązujących w danych kulturach; dopasowaniem form ubierania się do konwencji; dostępem do usług publicznych, np. dwujęzyczne programy edukacyjne; uwzględnieniem wśród różnego rodzaju rozwiązań prawnych przepisów dotyczących antydyskryminacji.

„Chachły i Lipowanie, czyli kto mieszka w Mirnem - o „etnicznej” tożsamości mieszkańców ukraińskiego Budziaku”, to referat w którym Autorka przybliżyła uczestnikom konferencji specyficzny status Besarabii, która jest przykładem konglomeratu kulturowego oraz raju dla dysydentów. Na tym obszarze w 1947 r. powstał pierwszy kołchoz, w roku 1957 zmieniono nazwę wsi na Minroje. Teren zamieszkują Lipowanie (Rosjanie) oraz Chachły (prawosławni Ukraińcy). Obszar cechuje się: brakiem silnych wpływów władzy centralnej; brakiem identyfikacji z jednostką państwa; ciagłymi zmianami przynależności terytorialnej; względną równością społeczną; przywiązaniem do wartości socjalistycznych. W podsumowaniu badań Olga Rodak przedstawiła określone wnioski. W badaniach na tym terenie nie można mówić o etniczności na gruncie teorii wypracowanych przez „zachodnich badaczy".

Referat „Alternatywne drogi poszukiwań własnej tożsamości etnicznej i kulturowej wśród polskiej arystokracji XIX w. na przykładzie hrab. Wacława Seweryna Rzewuskiego", autorstwa Filipa Kucery, przybliżył barwną postać Wacława Seweryna Rzewuskiego, który poszukiwania własnego siebie dokonywał przez kulturę Orientu. Dla 
niektórych był „dziwakiem” postrzeganym przez pryzmat swojego orientalnego stroju i stylu życia, dla innych poszukiwaczem i niezastąpionym znawcą w dziedzinie hodowli koni.

Następną referentką była Katarzyna Chlewińska (,Ślązacy - grupa in statu nascendi?”) W ostatnim czasie temat Ślązaków znów wywołuje wiele kontrowersji. Autorka starała się odpowiedzieć nam na pytanie: Kim właściwie Oni są?. Okazuje się, że w wielu aspektach są unikalni, zamieszkują region leżący w przeszłości na styku trzech krajów, trudno też nie mówić o specyficznej ich tożsamości. Jest to grupa, która musiała zmierzyć się z trudną, bardzo zmienną historią. Obecnie i oficjalnie określani są jako „mniejszość postulowana", która dąży do tego, by nazywać się grupą etniczną. Przytoczono kilka istniejących organizacji Ślązaków - ZLNŚ, Związek Ludu Narodowości Śląskiej, która walczy o rejestrację, ma poglądy nacjonalistyczne i antypolskie, RAŚ - Ruch Autonomii Śląska, powołuje się na autonomię Śląska w czasie II RP, SONS - Stowarzyszenie Osób Narodowości Śląskiej. Autorka doszła w swoich rozważaniach do konkurencyjnej wizji wspólnoty - Naród i Republika - odwołując się do idei republikańskich, a państwo polskie funkcjonuje w retoryce narodowej. Sprawa ich przynależności wciąż pozostaje otwarta.

Temat mniejszości romskiej często pojawiał się podczas konferencji; dużo uwagi poświęciła mu Elżbieta Piątek („Od wędrówki w taborach do szkolnej ławki - edukacja szansą czy zagrożeniem dla romskiej kultury”). Rozważania toczyły się więc w dużej mierze wokół przyczyn, dla których część Romów rezygnuje z edukacji. Ich kultura to wiele wyjazdów, długie wesela, pogrzeby, rodzina stawiana na pierwszym miejscu, dokładnie wyznaczone zadania każdej z płci. A polska szkoła? Wymaga nienagannej frekwencji, wielu godzin pracy, otwiera kobietom drogę do kariery zawodowej. Romowie boją się więc asymilacji, tego że ich kultura zostanie ukazana jako gorsza, że nauczyciele będą patrzeć na ich dzieci przez stereotypy, a propozycje powstania klas romskich uważają za powrót do gett. Temat okazał się trafny, pobudził pozostałych uczestników do wyrażania swoich spostrzeżeń, bo przecież każdy z nas na co dzień spotyka się z kulturą Romów, a problem rzeczywiście ma miejsce.

Następnym był, oprawiony prezentacją o barwnej Gruzji, referat Anny Katarzyny Charko, pt. „Od pokornego do zbuntowanego turysty” . Zrozumieć siebie i poznać inność. Referentka przeniosła nas na chwilę w rzeczywistość PRL, gdzie turystyka była kontrolowana, istniały różnie wspominane pociąi przyjaźni i świat za granicą był obcy. Korzystając z własnych doświadczeń, postanowiła przedstawić wyższość turystyki indywidualnej nad grupową. Człowiek w trakcie zorganizowanych wycieczek musi dostosować się do programu, a przez to ma niewielkie szanse na poznanie Innego. Samotna wyprawa to lęk, strach przed nieznanym, ale też wielka satysfakcja i poczucie wolności, możliwość podjęcia samodzielnej decyzji, w jakim stopniu chce się wejść w daną kulturę. Autorka zachęcała do podróży w głąb Gruzji, przytoczyła kilka charakterystycznych postaw jej mieszkańców, np. nie szanujesz starszych, nie szanujesz samego siebie; gość jest darem od Boga. Podkreśliła też jak wielką rolę w poznawaniu innej kultury ma jej kuchnia, ile przyjemności wnosi jej przenoszenie do swojego codziennego świata. Rozważania połączone były ze wspomnieniami. Autorka podsumowała cytatem Śliwińskiego: „Samotne podróżowanie uczy pokory”. 
Mateusz Piotr Gancewski odniósł się natomiast do mniejszości żydowskiej - w pracy „Antysemickie treści w publicystyce „Roli” w okresie rewolucji 1905-1907”. Na początku autor przybliżył nam historię powstania i główne założenia wspomnianego w tytule pisma. „Rola” mimo to, że była krytykowana przez elity, wyraźnie zaznaczyła się na kartach historii. Dziś uznajemy ją za prekursora antysemityzmu, nie bez powodu bowiem jeden z jej redaktorów określany był „żydojadem”, czy też „,̇ydożercą”. Kolejno autor przeszedł do analizy wpływu rewolucji z lat 1905-1907 na pobudzenie antysemickich poglądów w Kongresówce. Na długo więc przed rozpoczęciem II wojny światowej zaczęto mówić, że Żydzi są zagrożeniem, a asymilacja stanowi zło.

Sylwia Wodzińska poświęciła swoje wystąpienie tematowi: „Izrael: kraj Żydów, Arabów, Druzów czy Izraelczyków?”. Na początku Autorka przybliżyła nam historię powstania państwa izraelskiego, jego Deklarację Niepodległości opartą na wolności, sprawiedliwości i spokoju. Następnie pokazała jak bardzo różnorodny jest Izrael dziś. Jej mieszkańcy to Żydzi, Izraelczycy, Palestyńczycy i Rosjanie, są wyznawcami trzech religii - judaizmu, islamu oraz chrześcijaństwa. Miejsce, które miało zakończyć wieczną tułaczkę Żydów, stało się domem dla wielu kultur.

Przedostatnia wystąpiła Katarzyna Machtyl w referacie „Dialog i rozumienie. Spotkanie z Innym w koncepcji Michaila Bachtina”. Autorka przybliżyła uczestnikom poglądy Michaiła Bachtina, który kulturę postrzegał jako pule sensów, a za ich nośnika drugiego człowieka. Według niego żadna fotografia nie pokaże nam tego, co zobaczą w nas inni ludzie, jest więc tak, że człowiek istnieje dla drugiego człowieka, a co więcej Bachtin uważa, że człowiek formalnie istnieje w postaci ,ja” i ,innego”. Rozumie kulturę przez granicę bycia na pograniczu, uważa, że im bliżej granic, tym kultura bardziej żywa.

Ostatni wystapił Mikołaj Fryza, który przestawił referat pt. „Erasmus uczy czy bawi?". Z całą pewnością Erasmus to ciekawe doświadczenie, ale w jakim stopniu wiąże się ono z nauką i czy słusznie przyznawane są za niego dodatkowe punkty do Dyplomu? Uczestnicy przeprowadzonych badań jako jeden z głównych celów określają podszlifowanie języka i większości się to udaje, jednak to wspomnienia dotyczące poznawania uroków nocnego życia w nowych, uniwersyteckich miastach górują nad naukowymi osiągnięciami.

Konferencję - z całą pewnością organizatorzy, jak i uczestnicy - uznają za owocną i udaną. Niejednokrotnie dzięki owej interdyscyplinarności, zaskoczyło nas podejście do głównego tematu, co spowodowało różnorodność poszczególnych wystapień. Rozmowy prowadzone w kuluarach przyczyniły się z kolei do rozszerzenia i nawiązania wielu nowych znajomości, które miejmy nadzieję, jak zapowiadali uczestnicy, zostaną w przyszłości pogłębione i wykorzystane we współpracy naukowej. Organizatorzy konferencji zapowiedzieli druk przedstawionych referatów.

Weronika Janicka

Daria Pyła 